\title{
NEGOTIATING THE CRISIS OF SUCCESS: CONTEXTUAL THEOLOGY TEN YEARS INTO DEMOCRACY
}

\author{
Anthony Balcomb \\ School of Theology \\ University of KwaZulu-Natal
}

\begin{abstract}
Contextual theology has faced something of a crisis since the advent of democracy and the new dispensation in South Africa. The roots of the crisis may be found in the fact that much of the contextual theology of the past was based on the political agenda of erstwhile resistance movements that have become dominant political parties. This essay probes the nature of the crisis and looks to its solution in the future. It does this by locating the crisis in the realignment of political groupings in the past decade, examining its major theological weaknesses in the eighties and early nineties, and revisiting the issue of methodology around some crucial theological issues at stake in the new dispensation.
\end{abstract}

Key Concepts: Contextual theology, democracy, prophetic theology

\section{Introduction}

I will never forget the occasion when we first learnt, as a School of Theology, of the first signs of a tangible change of heart from the side of the apartheid government. It was at a staff retreat in February 1990 when about six of us, in those days the full quota of the staff of the SOT, heard the announcement that De Klerk had unbanned the ANC and was going to release Mandela. Whether it was a case of De Klerk and his party emerging from the trenches with a white flag in his hand or an attempt at a shrewd political move that went wrong, it has become clear, in retrospect, that the end of Nationalist Party rule was near. The announcement was greeted with a stunned silence. Someone broke the silence with the words "What do we do now?" It was as though we had already, in that brief moment, seen the writing on the wall for prophetic theology, and we did not like what we saw. Like Jonah, we had preached to Nineveh - never believing it would repent, and we did not like it when we were proven wrong.

That there is a crisis in prophetic theology has become increasingly clear. Molefe Tsele's description of the reports on the attempts to launch Kairos 2 is telling. "The words 'helplessness', 'despair', 'frustration'”, he says, "seemed to punctuate every report and by that denying any sense of celebration of the new era". "The utopia of the liberation struggle", comments Botman on these words of Tsele, "was not achieved".

But the word "utopia" by definition means "no place". Utopian visions are based on that most essential of biblical motifs - the motif of promise. And they exist because of that most

\footnotetext{
Botman R "The crisis in Contextual Theologies - the way ahead" in Towards an agenda for contextual theology, Speckman M and Kaufmann L (ed.) 2001, p. 118.
} 
essential of human capacities - the capacity for hope. If we do not have hope, we do not have promise, and if we do not have promise, we do not have a future, and if we do not have a future, we do not have God. When seen in this light, Tsele's words speak of a far deeper crisis than even their face value, which is stark enough, tends to suggest.

This came to me with a fresh and stunning impact recently when I was asked to examine a Masters thesis that told the personal stories of faith of fourteen leading theologians and activists of the struggle. ${ }^{2}$ The study revealed a startling anomie or loss of meaning in most of the people concerned in a post apartheid situation. It suggested that most had a) all but lost their faith in the course of the struggle, b) were either totally disillusioned with the church or found "solace" and "comfort" in a church that continued, quite clearly, to have little appreciation or understanding of their role in society, c) were clearly unable to articulate a theology that they could adhere to in a post-struggle situation, and d) longed for the emergence of a truly prophetic figure such as Desmond Tutu to give them meaning for a Christian existence in the new dispensation.

The crisis in contextual theology is not only one of vision and faith. It is also one of credibility. The crisis of vision lies with the protagonists of the tradition themselves. That of credibility lies not only with the theological community and the wider church but with the even broader community of "ordinary" people who are the proverbial "sheep without a shepherd". Behind and below all the revolutionary ferment of the masses during the days of struggle against apartheid there existed, and continues to exist, a simple faith in God, and an extraordinary, even unwarranted, belief in the church. This faith has undergone its own evolutionary journey away from Europe, been appropriated to one degree or another into prevailing cultural idioms, but continues to be shaped by a kind of orthodoxy long forsaken by many its European progenitors. Indeed a good alternative definition of orthodoxy is not correct belief, as is usually understood, but popular belief. It is to the adherents of this kind of faith, I think, that prophetic theology is somehow accountable, and to whom some kind of explanation is needed.

I would like in this essay to probe the nature of the crisis in the past and look to its solution in the future. I will do this firstly by locating the crisis in the realignment of political groupings in the past decade, examining what I consider to be its major theological weaknesses in the eighties and early nineties, revisiting the issue of methodology, and doing some theological reflection around what I consider to be the crucial theological issues at stake in the new dispensation.

I will proceed with my analysis by positing twelve theses and then briefly expanding on them. Before I do so I must point out that I locate myself within the tradition that I am critiquing. The weaknesses, shortcomings, and dangers, of this tradition might be so obvious to people in other traditions that much of what I say might already be passe. Indeed there were those who were quick to point them out twenty years ago. Such sceptics might have been proven right in many respects. Yet they themselves will need to explain how their theology met the crisis facing all of us twenty years ago. "Better to have loved and lost" someone once said, "then never to have loved at all".

The fact that I locate myself within a particular tradition will also limit my reflections on the topic of theology and theological education ten years into democracy generally. Hopefully, however, these reflections will help to open the discussion. I would also like to point out that I use the terms "contextual theology", "liberation theology", and "prophetic

Getman, EJ Analyzing Transition Narratives: Christian Leaders in Public Life in Post-Apartheid South Africa, unpublished Masters Thesis, University of Cape Town. 
theology" interchangeably. They all refer to a way of doing theology in South Africa that emerged, I think, from the early eighties. It must be pointed out also that this way of doing theology does not have a monopoly on contextualization, liberation, or prophecy in the SA situation. However, it is the only one that I know of that used as its hermeneutical key and raison d'etre the motif of liberation.

So to my first thesis:

1. The seismic shift in the political terrain over the past ten years has meant that the forces that were on the left of the spectrum are now to be found in the centre, those that were in the centre now find themselves on the right and those that were on the right have fallen off the edge into oblivion.

Movements in the earth's crust are sometimes known as movement of tectonic plates. If they are deep enough they cause earthquakes. This metaphor can be applied to the South African situation quite nicely because, theoretically, it is not the things on top of the earth's crust that in themselves change. If the movement in the earth's crust is severe enough it will result in the collapse of things on the earth's crust, but if not they will simply shift in the direction that the earth is moving (theoretically). The situation can be illustrated diagrammatically thus:

Before:

\begin{tabular}{|c|c|c|}
\hline $\begin{array}{l}\text { Mass democratic move- } \\
\text { ment, ANC (in exile), } \\
\text { prophetic church, ICT, } \\
\text { SACC, and "prophetic" } \\
\text { theology. }\end{array}$ & $\begin{array}{l}\text { Nationalist government with all } \\
\text { its apparatniks, official } \\
\text { opposition and other parties, } \\
\text { "mainline" church and "state" } \\
\text { theology. }\end{array}$ & $\begin{array}{l}\text { Right wing political parties } \\
\text { (eg CP and HNP), right } \\
\text { wing groupings, e.g. } \\
\text { AWB, right wing Christian } \\
\text { groupings (eg Kwasiza- } \\
\text { Bantu, some Dutch } \\
\text { Reformed churches, } \\
\text { CESA) }\end{array}$ \\
\hline
\end{tabular}

After:

\begin{tabular}{|c|c|c|}
\hline $\begin{array}{l}\text { Grassroots movements } \\
\text { e.g. Treatment Action } \\
\text { Campaign, Landless } \\
\text { Peoples Movement, } \\
\text { Coalition for a Basic } \\
\text { Income Grant, some } \\
\text { prophetic movements } \\
\text { e.g. ISB. }\end{array}$ & $\begin{array}{l}\text { ANC government, what used to } \\
\text { be the MDM, including the } \\
\text { trade unions, the Communist } \\
\text { party (?), "prophetic" church, } \\
\text { including the SACC. Old } \\
\text { prophetic theology which has } \\
\text { become the new "state" } \\
\text { theology?? }\end{array}$ & $\begin{array}{l}\text { All the parties that made } \\
\text { up the previous } \\
\text { government, official } \\
\text { opposition, mainline } \\
\text { church, } 3^{\text {rd }} \text { Way theology, } \\
\text { conservative Christian } \\
\text { groupings (e.g. CESA, } \\
\text { ACDP) }\end{array}$ \\
\hline
\end{tabular}

These diagrams may not, of course, be completely accurate. There might be debate around the location, for example, of the Communist Party, the "mainline" church, and the suggestion that the old prophetic theology is the new state theology, the role of Third way theology. The analysis may look a little simplistic. But what I want to stress is:

- The emergence of a new left, attempting to put pressure on the government to move left.

- The occupation, massively, of the middle ground by the ANC, with what used to be most of the prophetic church, now part of a centralist agenda because of its identification with the left wing in the past. 
- A movement on the right attempting to move the ANC to the right, with reactionary theological movements objecting to the liberalization of society. Notable in this grouping is the presence of right wing religious groupings that existed before the regime change but which have now become far more visible.

It is important to note that the movement to the right does not necessarily mean a movement to the right ideologically. On the whole the society has clearly become more "leftist" in its political agenda than in the previous regime. What has happened is that the "leftist" political agenda has now become the (centralist) agenda of the status quo, because of the seismic shift of the tectonic plates of society. This has opened up the space on the far left which is being filled by the movements not content with the progress made by the ANC led government and pushed the erstwhile right over the edge into oblivion.

The so-called democratic "miracle" that has taken place in the society is that this profound shift in forces has taken place precisely without the expected "earthquake" that would bring about a collapse in everything. We only have to look at the new constitution, formulated in a process that was open to as wide a possible spectrum of interest groups as was humanly possible, and the composition of parliament, where as wide a possible range of voices are heard in debate, that there has been a remarkable achievement indeed.

The accomplishments of the ANC led government have been significant. One analyst describes the new South African constitution as "one of the most luxuriously democratic instruments in the world". ${ }^{3}$ He says:

.... a democratic constitution, democratic institutions and substantially democratic practice have replaced the racial dictatorship of apartheid. South Africa's system of parliamentary government, if it works correctly, entrenches an advanced array of political, social and economic rights, is controlled by an extensive separation of powers (between legislature, executive and judiciary and between different levels of government), and is buttressed by an array of democracy-supporting institutions such as a Human Rights Commission, a Gender Commission, an Ombudsperson, and an Auditor-General's office. ${ }^{4}$

Moreover if we are to believe what they have said after the even stronger showing in the 2004 elections "We ain't", in the words of Ronald Reagan, "seen nothin' yet". They are now in a position, they claim, to prosecute the aims of the revolution and bring about economic prosperity for all. Indeed with $40 \%$ unemployment and a massive gulf between the rich and the poor still obtaining there is, indeed, much more to be done.

2. The identification of contextual theology in the eighties and nineties with a left wing political agenda has meant that its protagonists now occupy the middle ground of the status quo. This is the root cause of its crisis at the beginning of the third millennium.

The "magna carta" of prophetic theology in the early eighties was the Kairos document. Its analysis was simple. There was a left, a right, and a centre in theological alignment. "Prophetic" theology was on the left, "state" theology on the right, and "church" theology in the middle. The signs of the times were clear: To be prophetic you needed to be aligned with the forces of the revolution on the left. To occupy any other position was to "sell out" to the regime. Twenty years later regime change has meant that the same architects of Kairos have found themselves in the centre, by their own definition "sold out", through the

3 Southall R, "The 1999 Elections: Consolidating Democracy or Foreshadowing Decline?" Indicator South Africa, Vol 16, No 1 1999, p.19.

Southall R, p. 18. 
processes of history, to a new, albeit vastly changed, status quo. The logical consequence of identifying with a particular political agenda, in other words, was that as rapidly as this agenda comes to fruition so rapidly does their analysis become redundant and their theology cease to be prophetic.

3. By constructing its entire theology around the fulfilment of a particular political agenda, prophetic theology sowed the seeds of its own demise twenty years ago.

When I wrote my doctoral thesis at the end of the eighties I was convinced of three things. Firstly that the church had to take sides in the struggle, secondly that the apparently progressive alternatives to prophetic theology extant at the time were inadequate to the task of social transformation and were in fact pale reflections of a neo-liberal agenda, and thirdly that prophetic theology itself was of such thin substance theologically that it was not up to the task of providing an adequate theology for social transformation. I critiqued the notion of paradigm change as it was being mooted then because I could not see it fulfilling the basic requirements as articulated, for example, by Hans Kung. ${ }^{5}$ I found Boesak's appropriation of reformed theology far more convincing as I did Tutu's use of the motif of the sovereignty of Christ over all of life. My search took me to the ecumenical Indian theologian MM Thomas (who, I was to learn had, a profound influence on Boesak's political theology), whom I stumbled across when I found an evangelical critique of him in a doctoral thesis by an Indian student studying under Peter Beyerhaus. ${ }^{6}$ My reading of Thomas inspired the following words, written about twelve years ago:

But what if there is a way in which transcendence and uniqueness can take on quite opposite political significance (than that suggested by Third Way Theology, which translated not into commitment to transformation but ambivalence about it)? ... What if there is something other than the triumphalism of a theology of the status quo, the scepticism of some theologies of liberation, and the angst of a theology that cannot decide what it wants to legitimate and therefore legitimates the middle? What if there was a theology that was clear both in its commitment to radical transformation as well as to the uniqueness and identity of the Christian faith? A theology that inspires a holistic, integrist faith, committed to transformationary engagement with the world, and affirmative of the existence of a transcendent God who intervenes on the side of the poor and oppressed both to empower and judge their cause? A theology "realist" enough to be thoroughly cognizant of the inherent risks of political involvement and "utopian" enough to believe that if those risks are not taken a new society will not emerge? A theology that believes not only in the subversion of the old but the construction of the new? A theology that recognizes the need for rigorous social analysis but recognizes its primary task as theological reflection? ${ }^{7}$

I have quoted this section at length because I think that it not only reflects some of the major concerns of the theology that I was critiquing at the time but it also encapsulates the essential vision of a theology of liberation. I found in Thomas both a radical commitment to the "revolutionary ferments of our time" as well as a radical warning that these ferments should not be seen as the unqualified work of God. "The gospel of Jesus Christ" he said, should not be identified with any culture, political order, social ideology or moral system.

5 Kung H, "Paradigm change in theology - a proposal for discussion", in Paradigm Change in Theology, Kung $\mathrm{H}$ and Tracy D (eds.), Edinburgh: T\&T Clark 1989.

6 Sumithra S, Revolution as Revelation - A study of MM Thomas's Theology, International Christian Network, New Delhi 1984.

7 Balcomb A, Third Way Theology - Reconciliation, Revolution, and Reform in the South African Church during the 1980's, Pietermaritzburg: Cluster Publications 1993, p. 235. 
As the word and deed of God transcending all cultures, it is the divine power for their judgement and redemption. This is an understanding that gives the church the ability to relate itself positively but critically to all the creative movements of renewal of man and his world without absolutizing any of them. (Emphasis mine $)^{8}$

Recognizing that the judgement of God is on all struggles for justice makes just as much of a qualitative difference to one's commitment to these struggles as recognizing that in them God's hand is working in the first place. This difference is not only to do with commitment and religious zeal but with the recognition of the penultimate nature of all political involvement, the possibility that there is always something more, that the "not yet" demands that we continuously move beyond the "already", and that there shall always be an emancipation that yet awaits us - even until the parousia. I believe that if the political implications of such an eschatology had gripped us then we would not be sitting with the crisis in prophetic theology that we have now.

But it didn't. What we did was align ourselves, apparently without remainder, with the agenda of the Mass Democratic Movement.

4. We cannot expect the "old" prophets who are now the "new" politicians to think and act in any other way except as politicians. The roles of prophet and politician are mutually exclusive.

It is simply not possible to be prophetic and to be in government at the same time. The roles of politician and prophet are mutually exclusive, unable to be mixed, separate. They can only function correctly when they are seen as such. It does not necessarily follow that, just because many of the erstwhile prophets of struggle are now to be found in government, this constitutes a crisis in prophetic witness. The crisis is not in their "cooption" but in our inability to recognize the need for good politicians and good prophets paying attention to the same things in a completely different way. Effective engagement by the church with government depends on the recognition of this distinction just as much as it depends on the recognition, outlined above, of the radical discontinuity between the reign of God and the reign of humankind.

5. The attempts of the ANC led government, as well as all other political parties, to co-opt the church into the legitimation of their agendas should not be underestimated.

An HSRC investigation conducted some years ago indicated that of all the institutions in society the church was still trusted the most by the general populace. Politicians have never needed any reports to convince them that the religious community, especially the Christian one, was a fertile ground for votes. The church's openness and sensitivity to the needs of the marginalized and disadvantaged should be matched by its vigilance to resist cooption by political parties, especially those of the status quo. This does not mean that it should not be critically engaged with any political grouping whose agenda might be consonant, at particular moments, with its own prophetic agenda. However, all the attempts so far to bring dialogue between religious and political groupings have, in my opinion, indicated a co-optive agenda on the side of the latter and a somewhat gratuitous approach on the side of the former. We are still, in my opinion, far too awe-struck in the presence of our "eminences" the holders of political office. We need to remember that they are, above all, servants - servants of God and servants of the people. I trust we will be spared in South Africa the all too evident obeisance to political leaders that we see in other parts of Africa.

8 "A Christian interpretation of nationalism" in Towards a theology of contemporary ecumenism, WCC, Geneva 1978, p 49. 
6. With the identification of contextual theology with a particular political agenda there emerged an association, and an eventual identification, of theology with a certain kind of social analysis. This led to the fallacious equation: Good social analysis $=$ good theology.

I have expressed myself on this issue elsewhere and do not wish to repeat here what I have already said. ${ }^{9}$ Suffice it to say that the reductionism inherent in the processes of, for example, kairos theology, put brakes on theological reflection and rushed to political activism. We have had to live with the legacy of the equation between social analysis and theology ever since. The fact is that good social analysis is more important, and more difficult, now, than it ever has been. And the same goes for good theology. This leads me to my next thesis.

7. While the challenge to the church to take sides in the struggle against apartheid was great, it was not the greatest challenge that it faced. The greatest challenge was to anticipate, and theologically prepare for, the advent of apartheid's demise and the construction of a new society.

We made much of the "reading of the signs of the times" in the Kairos document, but what discernment did we really need when the whole world and at least three quarters of the population in South Africa knew apartheid was evil and could not last? The signs that we should have read were the signs of its demise and what would happen afterwards. When Hellenism and the gentiles were clamouring to come into the church Paul was laying the foundation to embrace them. When the barbarians were clamouring at the gates of Rome, Augustine was preparing for their entrance. When Aristotle reigned in the intellectual sphere, Thomas Aquinas was interpreting him for the church. When the Enlightenment threatened to destroy the faith, the German liberals reinterpreted the faith in Enlightenment terms. When the liberal agenda failed, Barth and company saved the ship from sinking. When Black Consciousness arose, Cone and the Black Theologians reinterpreted the faith in Black terms. When revolutions began against injustice in Latin America, the liberation theologians articulated the revolutions in terms of the Catholic tradition, which the Vatican could not ignore. In each case it was their ability to facilitate the new dispensation's arrival by articulating it theologically in such a way that both the faith and the church were enriched and strengthened. Their foresight, their insight, their statesmanship, and their faith, brought the church through. I am not saying that the church in South Africa is completely without these. But I think if we had read the signs of the times better, then we would have been doing better now.

Reading the signs of the times now is a great deal more difficult than it was in the eighties. Indeed this is one of the reasons for the flight that has taken place over the past decade from the kind of penetrating analysis that we did then.

8. The loss of direction for theology in the public arena has led progressive theology into one of two directions - a continuation of the trajectory of reductionism where concern for human rights or other "secular" issues are the sum total of a (non) theological agenda, or a retreat into a "business as usual" approach that is characterized by a new found dualism/pietism. This has created a vacuum in the socio-political arena that has quickly been filled by theology with a reactionist agenda.

$9 \quad$ "Is God in South Africa or are we still clearing our throats?" JTSA November 2001, p. 57-65. 
In many ways the situation now is a reverse of the situation ten years ago. Left wing theology is out of the public arena, right wing theology is in the public arena. Indeed, while the context provides an almost endless array of issues for a reactionary agenda - crime, aids, pornography, abortion, homosexuality, etc - all of which could be traced back to some form of "licentiousness" in the conservative mindset - a progressive agenda remains at best ambivalent about the situation and at worst confused. This is not helped by an uncritical fundamentalism that tends to immunize people across Africa to a more prophetic approach to theology as well as politics. The situation brings to mind these lines from Yeats' The Second Coming

The best lack all conviction, while the worst

Are full of passionate intensity. ${ }^{10}$

The challenge facing us is not to become less rigorous in our social analysis, in spite of the mistakes of the past, but more rigorous, while at the same time tapping into the rich theological traditions of Christian heritage that contain prophetic impulses. I will say more about these later.

\section{The achievements of the past ten years pose profound and unprecedented challenges for a prophetic agenda.}

That it seemed much easier to do prophetic theology ten years ago than it is now has already been pointed out. Reading the signs of the times is obviously going to be more difficult when the times appear good. But we should not allow the achievements that have been accomplished to muddy the waters when constructing a prophetic agenda. Indeed, it is these very successes that may provide the substance of this agenda. And while such an agenda must be influenced by the demand to privilege the interests of the poor and oppressed, such a category of people, while it clearly exists, is not as clearly demarcated now as it was then. It can no longer be defined, for example, simply in racial terms. In any case the mistakes of the past must surely caution us about simply identifying with another left wing agenda. By the same token identifying with the agenda of the status quo is equally as dangerous. There are many issues that demand our attention. These include the continued and possibly increasing gap between rich and poor, the continued gap between black and white (evidenced, for example, in as crass a reality as the main opposition party being overwhelmingly white and the main ruling party being overwhelmingly black), the HIV/Aids pandemic and the African renaissance. We could probably list many more. My concern is not so much what the issues are as to how they should be approached.

This leads me to the next thesis.

\section{We need to revisit, and take far more seriously than we used to, the hermeneutical circle as developed in the liberation tradition.}

The hermeneutical circle is precisely what it purports to be - an interpretive device that includes action and reflection. It is not exclusively about action. Neither is it exclusively about reflection. It is, firstly, about understanding the situation so that appropriate action takes place. And such an understanding is primarily about hearing the word of God in such a situation. Hearing the word of God in a situation involves, principally, being able to interpret the context in the light of the tradition and the tradition in the light of the context.

10 From The Collected Poems of WB Yeats Macmillan 1967, p 211. 
The process may involve a variety of things, including listening to a wide variety of understandings of the situation, especially to those most adversely affected by it (the "poor"), being informed as much as possible by a variety of disciplines from the human and social sciences, being informed as much as possible by a variety of traditions within the Christian faith that may have a bearing on the situation, and seeking the scriptures. The more penetrating the understanding of the situation, the more we will be able to integrate the variety of tools involved in the analysis, see beyond the obvious, face value of the issues concerned and discern the wisdom of God. We cannot discount, in our interpretation of the context, the problem of our own, and other, ideological biases. Christian anthropology assumes that wherever humans are involved our understanding will be partial, provisional, biased, selfish. To loosely quote Paul, if we think we know anything we know nothing, or, before we can know anything we must realize that we know nothing (1Cor.8:2). This is especially true where our own interests are involved.

May I be controversial for some of my contextual comrades in this regard? I am not one who believes that the perspective of the poor constitutes, ipso facto, the truth of a situation. Surrendering to the poor and the marginalized, or the rich and the powerful, or the educated and the enlightened, or indeed anyone else in society, the responsibility of discerning the word of God and reading the signs of the times is tantamount to relinquishing our prophetic responsibility. The epistemological privilege of the poor, which I uphold, does not mean that the perspective of the poor is the perspective of God. This does not mean that extraordinary wisdom and insight is not uncommon amongst "ordinary" people, including the poor and the marginalized. On the contrary, these are people who have a perspective that the privileged and powerful will not have, unless they are granted special dispensation by God's grace. And this can happen, though it is very rare and, when it does happen, may have drastic consequences for the one receiving the revelation (witness Francis of Assisi).

One of the most profound books I have ever read on this topic is Karl Mannheim's classic Ideology and Utopia. ${ }^{11} \mathrm{He}$ agrees with the Marxian notion of the ideological captivity of the rich but also moots a kind of "utopian" captivity of the poor. Just as the rich (and / or powerful) cannot "see the truth" because of their vested interests so the poor (and / or powerless) cannot "see the truth" because of their utopian expectations. The truth, for him, comes out of the interaction between both rich and poor, educated and uneducated. ${ }^{12}$ Another way of saying it is that access to the truth is through a kind of process of consultation and dialogue. It must involve transparency, humility, and accountability. All of these are good Christian virtues as well as democratic values.

The young South African democracy continues to be a kind of "experimental garden" (David Bosch) in which so many of these things are taking place. Take, for example, the HIV/Aids crisis. If there has ever been an issue that has challenged us it is this one. We are forced to understand the meaning of it because it is causing wholesale death and destruction. The visceral response that it elicits from us makes us expose our most vulnerable selves. The scientific facts are only one small part of the equation in this enormous problem. Studies in culture, psychology, and history are among the disciplines that demand to be used in our understanding of the pandemic. What is the meaning behind denial? What role does the issue of gender play? What is the meaning behind conspiracy

Kegan, Paul. London, 1936

2 This idea is developed by Nürnberger in his reflections on reconciliation. 
theories of Western involvement - still surfacing amongst some intellectuals? ${ }^{13}$ What is the meaning behind the taboos of diagnosis, cure, and disclosure? What is the meaning behind infected men raping three year old children?

All of these things cry out for interpretation and prophetic wisdom. This brings me to my penultimate thesis.

\section{One of the major challenges of contextual theology in South Africa at the beginning of the third millennium will be to revive the doctrine of sin and rediscover the truth of transcendence.}

One of the weaknesses, as well as strengths, of contextual theology has been its doctrine of sin. Strengths because it articulated more clearly than any other theology the structural dimension of sin, and weakness because it tended not to acknowledge the universality of sin, relegating it instead to certain sections of society. Similarly, the suspicion towards transcendence, with its roots in the Marxian doctrine of religion as the opiate of the people, has been a central and important tool in liberation hermeneutics. However, in the African context to dismiss the transcendent is to dismiss religion itself and to dismiss religion is to dismiss an essential part of life. It simply cannot be done. Both sin and transcendence need to be rehabilitated.

Transcendence as an epistemological category has made a remarkable comeback in some philosophical as well as scientific circles (for example with Alasdair MacIntyre, Charles Taylor, John Milbank, and George Ellis \& Nancy Murphy). This flies directly in the face of the Kantian and Cartesian traditions and makes theism a far more acceptable possibility philosophically. However, it is not the intention of these philosophers and scientists to act as apologists for theism. Their belief is that the world and the self are better understood from a philosophical and cosmological perspective if the notion of transcendence is taken seriously. The transcendence that they speak of is not so much the transcendence of the divine as a transcendence of the self - a kind of surpassing of the self. For Milbank, ${ }^{14}$ who draws upon the $19^{\text {th }}$ century thinker Blondel, transcendence is employed to understand all thought and action as a process of commitment, surrender, and denial. Ellis translates his understanding of transcendence into the theological notion of kenosis or self-emptying, which, he says, is built into the very nature of the universe. ${ }^{15}$ Closer to home, Nolan defines transcendence as the experience of becoming a (human) person beyond the dehumanising influences of the (apartheid) system. ${ }^{16}$ Bediako ${ }^{17}$ gives an African perspective on the subject and develops the idea of "immanent" transcendence in the African worldview. For Africans, he asserts, transcendence means the bringing together of the divine and the human in such a way that the divine is expressed within the human and not beyond it. All of these ideas provide extraordinarily rich material for new and transformative interpretations of the notion of transcendence.

I would like to turn our attention to the political significances of sin and transcendence. There were two traditions that had profound influence in Christian political theology in the

13 The well known traditionalist Credo Mutwa is the latest to hint at conspiracy theories about why a cure has not yet been found for Aids.

14 Milbank, J, Theology and Social Theory - Beyond Secular Reason, Blackwells 1995, p. 214.

15 Ellis, G and Murphy, N, On the Moral Nature of the Universe - Theology, Cosmology, and Ethics Fortress Press 1996.

16 Nolan, A, God in South Africa - The challenge of the Gospel, David Philip 1988, p. 187.

17 Bediako, K, Christianity in Africa - The renewal of a non-western religion, Orbis 1995, p 103. 
$20^{\text {th }}$ century - Christian Realism and Liberation Theology. Reinhold Niebuhr (remember the Serenity Prayer) is the name associated with the first and Gustavo Gutièrrez, amongst many others, with the second.$^{18}$ Christian Realism was based on the doctrine of sin and the fallenness of humankind. Lord Acton's maxim "power corrupts and absolute power corrupts absolutely" was an important part of this theology. Because humankind is sinful we cannot trust it to be able to handle power in such a way that would not corrupt them. Translated into political terms this meant that there had to be a balance of power so that no one group could dominate another. This theology clearly legitimated political systems that supported the division of the powers, such as democracy. It was also used to support the global balance of power and thus the arms race and the Cold War after 1945. Christian Realism is associated quintessentially with the arrival of political emancipation, the setting up of democratic institutions, the distribution of resources, and the establishment of stability. It assumes at least a modicum of power equality between all sections of society. Given this description it is clear that such a theology is more appropriate as a theology of the status quo in the present South Africa. Emancipation has arrived, power has been given to the people, democracy is established, the kingdom has come, a stable, crime free, prosperous society must now be delivered. There is little room, in such a scenario, for "something more". The "not yet" has been swallowed up by the "already". The utopian vision is dead.

Liberation theology, on the other hand, feeds off the future. The promised land is an eschatological (not a present) reality. It is a theology of those who do not have but who expect to have. Hope drives the poor to action. The realization of the promise, though not far, is yet to come. The "already" is a place of inequality, injustice, a vale of tears. The "not yet" is a large, looming, utopian vision of freedom, equality, and prosperity. Gutièrrez brilliantly describes this coming together of eschatology and history:

The rediscovery of the eschatological dimension in theology has ... led us to consider the central role of historical praxis. Indeed, if human history is above all else an opening to the future, then it is a task, a political occupation, through which man (sic) opens himself to the gift which gives human history its transcendent meaning: the full and definitive encounter with the Lord and with other men. ${ }^{19}$

The essential difference between these two theological paradigms is the absence in one and presence in the other of an eschatological and transcendent dimension that has a direct bearing on the transforming power of God through the actions of humankind in history. I have already suggested that all the ingredients for the "Realism" paradigm are present in the South African situation. Does this mean that there is no more room for the liberation paradigm? Fukuyama argues that utopianism as a global political motif died with the end of communism and the collapse of the Soviet Union. ${ }^{20}$ Political liberalism and market economics are now the global order of the day.

The question is: Should we succumb to such an analysis? The question could be framed in another way, namely, "Can the Christian faith do without eschatology?" Clearly it cannot. To collapse the "not yet" into the "already" is to assume that the reign of God has already arrived and that we have a perfect society. But for millions in South Africa (all, presumably of the $40 \%$ who are unemployed) the reign of God has clearly not arrived. For

18 I make an extensive comparison between Third Way Theology and Christian Realism in my book Third Way Theology. I point out that Realism has been used by agendas on both the left and right of the political spectrum. (p.143)

19 Gutierrez G, A Theology of Liberation - History, Politics, and Salvation, SCM Press 1973, p. 10.

20 Fukuyama F, The End of History and the Last Man, Hamish Hamilton 1992. 
these the "not yet" is the dominant reality. Freedom has surely never been nearer now than it was before for those not yet liberated from poverty. And the pain of freedom's nearness is all the more acute when your erstwhile comrades are seen to be dining at the tables of the rich and you are still hungry; when several million Rands are spent in celebrating the outcome of the 2004 elections and you do not yet have a roof over your head; when 300 billion rand is sitting in the reserve bank and you have no job; when you are dying of Aidsrelated diseases and you know that millions of Rands for free ARV's are stuck in some bureaucratic logjam.

Christian theology, in other words, must always have a "not yet". Without it theology ceases to be Christian and ceases to be theology. By the same token, however, the question may also be asked: "Can the Christian faith do without the doctrine of sin?" Clearly it cannot. To remove the doctrine of $\sin$ is to trust too much in humankind and its ability to bring about our salvation. To remove the doctrine of sin is to cease to throw ourselves on a merciful God. To remove the doctrine of sin is to remove the reason for democracy.

Clearly there are other Christian doctrines that need to be applied when doing political theology. I have mentioned sin and transcendence as the most important that come to mind in the context of the South African democracy. The point about these doctrines is that they need to be rehabilitated into the public arena, more especially this (the South African) public arena.

This brings me to my final thesis.

12 The crisis in both the practice and credibility of contextual theology has probably led to its sharp decline in institutions where theology is being taught. This is a dangerous situation because it suggests that future generations of theologians are not being given the theological and critical skills for prophetic engagement in society.

My guess is that the "business as usual" approach is the norm in most theological institutions in South Africa today. This is exacerbated by the "success" of the democratic changes. Unless you find yourself in the reactionary camp and you do not like what is happening in society, the tendency will be for you to think everything is in order and that you therefore need to return to spiritual concerns. So the emphasis in theological training will be to train pastors and missionaries in the exercise of their duties in terms of their church traditions. History has taught us that the church, unless very specifically directed otherwise, will drift ideologically either towards the right or centre of the society in which it finds itself. Religion becomes a haven of escape for those on the margins of society and a means of legitimation of the status quo for those in the centre. If theology is not contextualized in South Africa, the future of the church will probably be in this direction. In such a situation the church will find itself continuously lagging behind the state, at best, making no difference, and, at worst, simply legitimating the status quo. The religious interventions that do take place will happen on the right, not the left, of the ideological spectrum. The contextualization of theology is therefore vital if the church is to become proactive, and not reactive, in society.

This leads me to my conclusion. 


\section{Conclusion}

The contextualization of theology in the new democratic dispensation is under threat. The successes of the new regime mean that the tendency is going to be to withdraw from prophetic engagement with the government and from society. The need for contextualization, therefore, is as urgent now as it always has been. This means that the challenges for theology and theological education are particularly strong at this juncture of our history. The challenge is to continue to revisit and apply the long tested truth of Christ, salvation, and eschatology, to continue to revisit and practice the long tested virtues of faith, hope, and love, and to continue to do all this and more through prayer, the study of scripture, and rigorous application of all the tools available to us for the task. 